\title{
MENINGKATKAN KONSENTRASI BELAJAR SISWA DENGAN BIMBINGAN KLASIKAL METODE PROJECT BASED LEARNING SMA NEGERI 6 BARABAI \\ Noor Ifansyah \\ SMA Negeri 6 Barabai
}

\begin{abstract}
ABSTRAK
Siswa hendaknya memiliki kemampuan konsentrasi saat proses belajar berlangsung sehinga mampu mengikuti proses belajar dan mencapai tujuan pembelajaran yang diharapkan.layanan bimbingan klasikal melalui metode project based learning bertujuan untuk meningkatkan konsentrasi dalam mengikuti pembelajaran.partisipan dalam kegiatan ini adalah siswa kelas XI MIA 1 SMA Negeri 6 Barabai dengan jumlah 24 orang . Kegiatan layanan dilakukan melalui tiga tahap yakni tahap awal, tahap inti, dan tahap penutup.
\end{abstract}

Kata Kunci: konsentrasi belajar, bimbingan klasikal, project based learning

\section{PENDAHULUAN}

Belajar adalah proses interaksi antara individu dengan sumber belajar yang menghasilkan suatu perubahan tingkah laku. Slameto (2003: 2). Pada dasarnya tujuan utama dari kegiatan belajar mengajar adalah agar siswa menguasai materi pelajaran sesuai dengan kompetensi yang telah ditetapkan. Namun ketika dalam kegiatan belajar mengajar di kelas, banyak pelajar yang menganggap jika ruang kelas merupakan sebuah penjara yang tidak menyenangkan. Sehingga siswa menganggap belajar sebagai beban dan merasa tidak nyaman dalam belajar.Kegiatan belajar mengajar di kelas tak dapat dipisahkan dari sosok guru. Peranan guru sebagai fasilitator dan juga motivator, menjadi hal yang sangat penting dalam berlangsungnya proses pembelajaran yang efektif. Dan proses belajar mengajar yang efektif itu sendiri memerlukan konsentrasi belajar dari peserta didik.

Konsentrasi belajar adalah kemampuan untuk mengarahkan segala pikiran dan perbuatan sehingga mampu mempelajari suatu hal dengan baik. Pada saat mempelajari materi di kelas, peserta didik seringkali mengalami berbagai macam gangguan (noise) yang berasal dari dalam dan luar diri sehingga dapat mengganggu konsentrasi belajar. Pada saat belajar, kadang kala tanpa disadari muncul pikiran mengenai masalahmasalah lama dan keinginan lain menjadi pengganggu aktivitas belajar kita. Suasanabelajar dimana kelas penuh, cuaca panas, suara bising dari luar ruangan juga seringkali membuat siswa mengalami gangguan sehingga sulit untuk berkonsentrasi. Gangguan konsentrasi belajar banyak dialami peserta didik terutama saat mempelajari mata pelajaran yang mempunyai tingkat kesulitan tinggi. Kesulitan menjaga konsentrasi belajar juga semakin bertambah jika peserta didik terpaksa mempelajari materi pelajaran yang tidak disukainya (Ikawati, 2015).

Siswa yang tidak dapat memfokuskan pikiran terhadap materi pembelajaran disebabkan oleh beberapa hal misalnya: guru yang mengajar dengan metode pembelajaran klasikal atau kelompok menyebabkan siswa dianggap memiliki kemampuan berpikir yang sama; kurangnya keterampilan guru di dalam mengelola kelas sehingga metode pembelajaran yang diberikan bersifat monoton dan kurang bervariasi sehingga menyebabkan siswa menjadi pasif dan hanya mengandalkan guru; dan ditambah suasana di kelas yang panas, sesak, dan terkadang bising yang memunculkan 
Jurnal Inovasi BK,Volume 1, Nomor 2 Desember 2019 gangguan suara sehingga suasana di kelas menjadi sangat tidak nyaman dan kondusif untuk belajar (Aviana \& Hidayah, 2015).

Usaha untuk meningkatkan konsentrasi belajar siswa dapat dilakukan melalui bimbingan klasikal. Bimbingan klasikal atau bimbingan kelompok adalah jenis layanan yang ada pada konseling dengan menggunakan dinamika kelompok untuk membahas permasalahan yang dialami peserta didik. Melalui diskusi maka diharapkan peserta didik memperoleh pemahaman masalah sehingga mampu bertindak secara tepat. Pada bimbingan kelompok setiap anggota berhak mengemukakan pengalaman dan pendapatnya sehingga menambah wawasan anggota (Maiseptian et al., 2017). Selain itu, melalui bimbingan kelompok, siswa juga dapat mengurangi sikap negatif siswa seperti pemalu, suka memotong pembicaraan orang lain, dan perilaku tidak menghargai pendapat lain, serta menimbulkan sikap percaya, memahami, melatih kemampuan berkomunikasi, memecahkan konflik melalui cara konstruktif antar peserta didik (Erlangga, 2017).

\section{METODE}

Pada metode penelitian ini peneliti menggunakan penelitian pendekatan deskriptif yang mana dengan melihat, merasakan mengamati dan sebagainya suatu obyek dan subyek terhadap responden berjumlah 12 orang.

Menurut Machfudz (dalam Rizqiyah, 2016) Penelitian deskriptif adalah penelitian yang bermaksud untuk membuat deskripsi, gambaran atau lukisan secara sistematis, faktual dan akurat mengenai fakta-fakta, sifat-sifat serta hubungan antar fenomena yang diselidiki. maka peneliti menggunakan bahwa penelitian atau pendekatan yang akan digunakan dalam penelitian ini yaitu pendekatan deskriptif kulitatif, karena seperti yang dijelaskan di atas bahwa data deskriptif adalah data yang dapat diamati.
Metode pengambilan data dalam penelitian ini adalah observasi, wawancara dan dokumentasi. Dalam metode observasi yang digunakan adalah observasi non partisipan, yaitu dalam proses kegiatan mengadakan pengamatan langsung di SMP Negeri 1 Katingan Tengah, namun penulis tidak secara langsung berpartisipasi atau ikut serta dalam kegiatan (Hadari Nawawi, 2000). Dalam metode wawancara, jenis wawancara digunakan adalah bebas terpimpin, pedoman wawancara yang hanya berupa garis besarnya saja tentang hal-hal yang ditanyakan dan sesuai dengan data yang diteliti (Ahmad Tanzeh, 2011).

Dalam metode dokumentasi, digunakan untuk mendapatkan sejumlah data, yaitu tentang letak geografis, sejarah berdiri dan perkembangan sekolah, visi-misi dan tujuan sekolah, struktur organisasi, sarana dan prasarana, keadaan dan kondisi guru dan siswa, serta data terkait dengan peran guru BK dalam penyesuaian diri siswa dengan lingkungan sekolah baru.

Data yang telah terkumpul pada penelitian ini akan dianalisis sesuai dengan tahapan menurut Miles \& Huberman (Sugiono, 2016), yaitu reduksi data, penyajian data dan penarikan Kesimpulan.

\section{HASIL DAN PEMBAHASAN}

Peneliti menggunakan analisis data deskriptif untuk mencari tingkat persentase konsentrasi belajar peserta didik berdasarkan skala konsentrasi belajar. Peneliti menggunakan analisis deskriptif yaitu dengan menjelaskan hasil perhitungan skor hasil Penilaian Segera (laiseg). Skala konsentrasi belajar menggunakan skor 0 sampai 2. Berdasarkan perhitungan di atas maka kriteria penilaian tingkat peningkatan konsentrasi belajar kriteria penilaian tingkat konsentrasi belajar yang digunakan peneliti melalui interval perhitungan. Untuk kriteria peserta didik dari konsentrasi belajar Sangat Rendah mulai 40\% - 46\%, kriteria Rendah 47\% - 53\%, kriteria Sedang 
54\% - 60\%, kriteria Tinggi $61 \%-67 \%$, dan untuk kriteria Sangat Tinggi 68\% - 100\%.

jumlah total peserta didik terdiri dari 12 orang, yang mana sejumlah 7 orang mendapatkan skor Sangat Tinggi (74\%). Peserta didik yang berjumlah 4 orang mendapatkan skor Tinggi (23\%), dan tersisa 1 orang yang mendapatkan skor sedang (2\%).Namun secara keseluruhan peserta didik menunjukkan tingkat konsentrasi yang Sangat Tinggi. Hal ini menunjukkan proses pemberian layanan secara klasikal melalui metode Project based learning efektif dilakukan untuk meningkatkan konsentrasi peserta didik.

Setiap peserta didik dituntut untuk bekerja dalam kelompok melalui rancangan tertentu yang sudah dipersiapkan untuk menyampaikan hasil diskusinya agar membuat setiap peserta didik menjadi aktif dan fokus untuk melakukan proses diskusi. Langkah tersebut diambil karena dengan menggunakan metode pembelajaran project based learning, peserta didik akan termotivasi untuk dapat mengungkapkan ide di dalam wadah kelompok sendiri maupun kelompok lainnya. Pada akhirnya dari proses diskusi, konsentrasi peserta didik dapat menjadi lebih terlatih terhadap proses pembelajaran yang diterima sehingga memunculkan motivasi dan minat peserta didik untuk mengembangkan konsentrasi belajarnya terhadap materi atau bahan pelajaran. Hasil kegiatan menunjukkan konsentrasi dalam berdiskusi membahas topik yang didapatkan sangat efektif dilakukan. Hal ini ditunjukkan dengan hasil karya peserta didik yang dituangkan melalui media kertas dan keaktifan saat berpendapat Hasil kegiatan menunjukkan konsentrasi dalam berdiskusi membahas topik yang didapatkan sangat efektif dilakukan. Hal ini ditunjukkan dengan hasil peserta didik yang dituangkan melalui media kertas dan keaktifan saat berpendapat dalam kelompok. Setelah dari diskusi, masing-masing anggota kelompok menunjuk salah satu perwakilan untuk menyampaikan hasil diskusi di depan kelas. Ketika tahap inti akan berakhir, peneliti kembali menjelaskan topik yang dibahas masing-masing kelompok, agar semakin menambah pemahaman mereka untuk mengembangkan konsentrasi saat belajar ketika selesai dari kegiatan ini. Selanjutnya peneliti mengajak peserta didik untuk menyimak PPT dan menganalisa apa yang terjadi dari permasalahan tersebut. Beberapa peserta didik kemudian mengangkat tangan dan menjelaskan isi dari PPT tersebut yang dikaitkan ke semua topik kegiatan yang sudah dilakukan. Slide PPT yang diberikan memberikan pemahaman kepada peserta didik pentingnya konsentrasi saat belajar.

Ketika peserta didik bisa memusatkan perhatiannya dan mengabaikan stimulus dari luar peserta didik akan lebih mudah memahami materi atau bahan ajar yang dipelajar namun ketika peserta didik tidak bisa memusatkan perhatiaannya dan fokus dengan hal-hal lain, peserta didik pasti akan sulit untuk memahami materi yang dipelajar. Semuanya tergantung kepada peserta didik dengan melihat faktorfaktor yang ada dalam diri peserta didik, serta peserta didik perlu memiliki gaya belajar yang baik untuk membantu konsentrasi belajarnya. Setelah peneliti menyimpulkan kegiatan yang telah dilakukan, peneliti memberikan evaluasi ke peserta didik dengan harapan melihat sejauh mana proses kegiatan dari layanan yang diberikan apakah membantu peserta didik memahami dan mengembangkan konsentrasi belajarnya. Tentunya dari kegiatan ini, guru kembali memberikan motivasi dan penguatan kepada peserta didik untuk mendorong peserta didik mengembangkan konsentrasi dalam mengikuti pelajaran yang sedang dihadapi baik di rumah maupun di sekolah. Guru mengakhiri kegiatan dengan memberikan salam dan ucapan terima kasih kepada peserta didik. 


\section{KESIMPULAN}

Berdasarkan hasil kegiatan yang telah dilakukan menunjukkan kegiatan yang dialukan dapat meningkatkan konsentrasi belajar siswa kelas XI MIA 1 di SMAN 6 Barabai. Siswa seringkali merasa bosan ditengah-tengah pelajaran ketika guru menyampaikan materi pelajaran. Sudah pasti, guru harus memliki pengetahuan bagaimana cara mengatasi kasus seperti itu. Ketika siswa bosan dalam mengikuti pelajaran, itu merupakan salah satu ciri bahwa siswa telah kehilangan konsentrasi belajarnya. Maka dari itu guru sebaiknya melakukan upaya untuk meningkatkan konsentrasi siswanya, agar siswa dapat mengikuti pelajaran dengan focus dan siswa bisa dengan mudah menangkap materi yang diberikan.

\section{DAFTAR PUSTAKA}

Aviana, R., \& Hidayah, F. (2015). Pengaruh Tingkat Konsentrasi Belajar Siswa Terhadap Daya Pemahaman Materi Pada Pembelajaran Kimia Di Sma Negeri 2 Batang. Jurnal Pendidikan Sains Universitas Muhammadiyah Semarang, 3(1), 30-33. https://doi.org/10.26714/jps.3.1.201 5.30-33

Erlangga, E. (2017). Bimbingan Kelompok Meningkatkan Keterampilan Berkomunikasi Siswa. Psympathic: Jurnal Ilmiah Psikologi, 4(1), 149156.

https://doi.org/10.15575/psy.v4i1.13 32

Maiseptian, F., -, M., \& -, Y. (2017). Efektivitas Layanan Bimbingan Kelompok Dalam Meningkatkan Kecerdasan Emosional Siswa. Jurnal Penelitian Bimbingan Dan Konseling, 2(2), 1-8. https://doi.org/10.30870/jpbk.v2i2.3 057
Ikawati, M. P. D. (2015). Upaya Meningkatkan Konsentrasi Belajar Siswa KMS (Kartu Menuju Sejahtera) Menggunakan Konseling Kelompok Bagi Siswa. Psikopedagogia Jurnal Bimbingan Dan Konseling, 4(2), 158. https://doi.org/10.12928/psikopedag ogia.v4i2.4484

Mindari, T., \& Supriyo. (2015). Meningkatkan Konsentrasi Belajar Melalui Layanan Bimbingan Kelompok dengan Teknik Permainan. Indonesian Journal of Guidance and Counseling, 4(2), 6571.

Izzati, U. A., \& Puspitadewi, N. W. S. (2013). Penerapan Relaksasi Atensi Untuk Meningkatkan Konsentrasi Belajar Pada Siswa Smk. Jurnal Psikologi Teori Dan Terapan, 3(2), 103.

Darmansyah. 2010. Strategi Pembelajaran Menyenangkan Dengan Humor. Jakarta: PT Bumi Aksara.

Hariyanto. 2010. Pengertian Belajar Menurut Ahli. (online). Tersedia http://belajarpsikologi.com/pengertia n-belajar-menurut-ahli/. (diakses: 15 Mei 2016).

Fanny, R. (2009). Brain Gym Tingkatkan Potensi Seseorang. (online).Tersedia:http://kiatsehat.co $\mathrm{m} / 2009$. (diakses tanggal $18 \mathrm{Mei}$ 2016).

Barbara K. Given. 2007. Brain-Based Teaching. Bandung: PT Mizan Pustaka.

Dimyati, dan Mudjiono. 2006. Belajar dan Pembelajaran. Jakarta: Rineka Cipta. 